\section{Imperial Airways New Programme}

SPEAKIng at the annual meeting of Imperial Airways, Sir Eric Geddes outlined the possibilities of, at least experimental, passenger- and mail-carrying operations across the North Atlantic next summer. A 'Mayo' composite aircraft in which a large seaplane, with good 'get off' characteristics, carries a smaller long-distance machine upon its back, releasing it at a suitable height, and also a large flying boat of more normal design are under construction, both of them having sufficient range to fly the Atlantic with adequate reserve. The westward journey will probably be London, Azores, Bermuda, New York, the latter stage being operated in conjunction with Pan-American Airways. Eastwards the direct line New York, Port Botwood (Newfoundland), Cork or Bantry Bay (Ireland), London has been surveyed, although the intermediate stations in Canada and Ireland are not yet definitely settled. The longer route outwards is necessary as stops are needed for refuelling. The prevailing west to east winds make it impossible to fly the more direct route, without landing between Ireland and Newfoundland, with sufficient fuel and still to have an economic loadcarrying capacity. On the return journey, this follow ing wind not only reduces the air mileage but also increases the relative speed.

The distance from Newfoundland to Ireland is about 1,900 miles, and a flying boat with only a little more nominal air endurance will actually have a considerable reserve, owing to the almost constant following wind. There are also envisaged extensions to this route across Canada to Vancouver, Khartoum to Nigeria from the England-South Africa route, and Hong-Kong to Penang from the main Australian route. Sir Erie stressed the fact that there is a great difference between speeds technically possible and those commercially practicable, and stated that there is a greater demand for a reduction in fares than for an increase in speed. Nevertheless, the new aircraft on order will give substantial increases in speed next summer, subject to ground organisation being provided of a suitable standard. For example, it is expected to reach Australia in seven days, South Africa in four days and India in three, with normal schedule working.

\section{Rebuilding Birkbeck College}

Is the murky atmosphere of a Strand tavern on a dreary December evening more than a century ago, the germ of a great ideal first struggled into existence. George Birkbeck, who presided on the occasion, was a man of vision, but it is to be doubted whether even he had more than a glimmering of what the future held for his latest child. Since that nightthe gathering of a couple of thousand working men did not disperse until 3 a.m.-Birkbeck College has become an integral part of the body scientific. The appeal launched at the Mansion House on November 7 for funds for rebuilding Birkbeck College is of the highest importance not only to the College alumni but also to scientific workers throughout Great Britain. The Lord Mayor (Sir Stephen Killick), an old student of the College, presided, supported by the Duke of York, president of the College, accompanied by the Duchess, the Archbishop of Canterbury, the Vice-Chancellor of the University of London (Dr. Eason) and the chairman of the Governing Body (Mr. W. L. Hichens). Owing to the general election, Mr. Ramsay MacDonald, another old student, was unable to attend, but wrote a letter strongly supporting the appeal.

THE Lord Mayor said the present buildings of Birkbeck College are inadequate, and that the University of London has offered a position for a new building on the Bloomsbury site. Generous grants towards the rebuilding fund have been offered by the University, the London County Council and the City Corporation. About half of the $£ 250,000$ required has been promised. The ViceChancellor contributed interesting information about the work of the College, referring particularly to its 200 post-graduate research workers and to Prof. P. M. S. Blackett's research work on cosmic rays, to which $£ 1,150$ has been contributed from the Mond Fund of the Royal Society. As the Archbishop of Canterbury pointed out, the movement to bring the worker to the university rather than the reverse process is an ideal to which the energies of all should be directed. The academic record of Birkbeck staff is high, and an increasing volume of significant research is being prosecuted under their direction; research which, in the words of Mr. Ramsay MacDonald, is fraught with possibilities of the highest importance to our great industrial centres. The appeal merits a speedy and generous response. Let him who hath give; and let him who hath not, proclaim the worthiness of a common cause.

\section{School and Museum in London Education}

IN order to take fuller advantage of the exceptional opportunities afforded by the museums of London of adding background to the curriculum of the schools, the London County Council decided early in the current year to add to the staff of its inspectorate an officer who would serve as a liaison between museum and school. School visits to the museums have long figured in the time-table; but it had become evident that some organisation of objective was necessary to secure the full return for the time which these visits demand. The resolution of the Council has been given effect by the appointment of Dr. Louis W. G. Malcolm to the post; and arrangements have been made already under his supervision for an extension of the system of school visits and lectures in the museums to cover a wide field of subjects of topical and educational interest. In the Imperial Institute, for example, geographical films are being shown and lectures given on the Mediterranean, Malta, Gibraltar, Cyprus and Suez, and these will be followed by illustrations of the industries and occupations of the more distant parts of the Empire. In the London Museum, the history of London from prehistoric to Stuart times is to be demanstrated. Among other 